Aldi Kuqo*, Ilirjana Boci, Sonila Vito, Sidorela Vishkulli

University of Tirana, Faculty of Natural Sciences, Department of Industrial Chemistry, Tirana, Albania
Scientific paper

ISSN 0351-9465, E-ISSN 2466-2585

UDC:620.16.199:666.973.2

doi:10.5937/zasmat1804519K

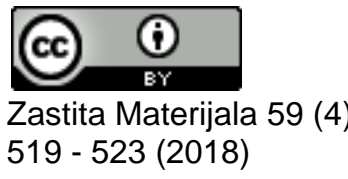

\title{
Mechanical properties of lightweight concrete composed with Posidonia Oceanica fibres
}

\begin{abstract}
This study aims to the preparation of lightweight concrete with lignocelulosic fibres from Posidonia Oceanica balls. PO balls can be found in large amounts along the Mediterranean shores. Based on previous scientific research, it has been found that they possess have very interesting properties such fire resistance, moisture resistance and thermal resistance and can serve as a raw material for the production of composites at a very low cost. In the current research it is attempted to examine flexural and compressive resistance of the $P O$ fibres concrete. Results obtained from the tests indicate that $P O$ fibres can be used as a substitute of aggregate producing lightweight concrete.
\end{abstract}

Keywords: Natural fibres, Sea grass, Posidonia Oceanica, Lightweight concrete.

\section{INTRODUCTION}

Building Industry promotes the development of national economy and urbanization process of a country. On the other hand, according to many authors construction industry which includes construction process, materials production and other such as transportation, will lead to $40 \%$ of all emissions in the future [1]. The building sector accounts $65 \%$ and $42 \%$ of energy consumption in the United States and European Union. Since the impact of building activities being more and more obvious the construction of green building is implemented in the last.

Green building refers to structure, green innovative materials and the application of processes that are environmentally responsible and resource efficient throughout a building's life cycle. Green building save resources to maximum extent, including energy saving, water saving and land saving so as to protect the environment and to reduce pollution [2]. In the building, construction materials are the most important part. Apart from the large amount of energy required for their production, it is the part exposed directly to people.

\footnotetext{
*Corresponding author: Aldi Kuqo

E-mail: aldi.kuqo@fshn.edu.al

Paper received: 15.10.2018.

Paper accepted: 08.11.2018.

Paper is available on the website: www.idk.org.rs/journal
}

Advancements in green construction have initiated the research towards new innovative materials mainly composite materials, low cost and environmentally friendly. Since many countries have started to implement practices and promotion of green building, the interest for the exploitation of natural resources (in local level) has been intensified. There is tremendous growth of interest for the use of natural raw materials as well as for agro-industrial waste.

Natural fibres have been used in construction for centuries in roofs, walls, insulation and other structural and non structural applications but after the emerging of conventional building materials like concrete and steel they were abandoned since they had not technological importance. Nowadays, natural fibres are gaining interest since they can be used for the production of composite materials. Fibres such as Hemp [3], Sisal [4,5], Jute [6] and others have been used as reinforcing agents in concrete blocks. It is assumed that these fibres can successfully replace steel fibres improving some and worsening some other properties of the final product.

Apart from many traditional fibres used in building, lately the interest for a new, low cost lignocellulosic fiber with large availability, has emerged. Posidonia Oceanica balls are marine 
biomass which can be found in many sea shores of the Mediterranean region. PO waste includes $\mathrm{PO}$ balls and leaves. Both parts of PO are washed ashore the coast due to bad weather conditions after they separate from the PO marine plant. Their presence in the coastline often worsens its view, thus, it is considered a waste that has to be removed especially in bathing seasons. PO balls have been studied from many authors. Allegue L. et al. has studied the mechanical properties of reinforced cement using various ratios and fibres and cement [7]. Mechanical and insulation properties have been investigated from many authors for the purpose of the production of bioplastics and other composites [8-10].

The objective of this study is to examine some of the mechanical properties of concrete-fibre composite material. The flexural and compressive resistance was determined.

\section{MATERIALS AND METHODS}

\subsection{Raw materials}

PO fibres were harvested randomly in the coastal area of Durres (Albania) in mid-April (Figure 1). After the collection process fibres were dried naturally. In parallel, a small portion of fibres was weighed and dried in an oven at $60{ }^{\circ} \mathrm{C}$ for two hours. The moisture content of fibres was $4 \%$. In addition apparent density of $\mathrm{PO}$ fibers was determined. It resulted $35 \mathrm{~kg} / \mathrm{m}^{3}$. Portland cement was provided by Colacem $(32.5 \mathrm{R})$ and fine aggregate sand was provided by a stone quarry. The bulk density of the fine aggregate was 1610 $\mathrm{kg} / \mathrm{m}^{3}$.

Table 1. Presentation of concrete constituents*

Tabela 1. Prezentacija betonskih sastojaka*

\begin{tabular}{|c|c|c|c|c|c|}
\hline Nr. & $\begin{array}{c}\text { Cement } \\
\text { content }(\mathrm{g})\end{array}$ & $\begin{array}{c}\text { Aggregate } \\
\text { content }(\mathrm{g})\end{array}$ & $\begin{array}{c}\text { Fibres } \\
\text { content }(\mathrm{g})\end{array}$ & Aggregate : PO Fibres (w/w) & $\begin{array}{c}\text { Aggregate : PO } \\
\text { Fibres (V/V) }\end{array}$ \\
\hline 1 & 100 & 400 & 0 & - & - \\
\hline 2 & 100 & 400 & 10 & $40: 1$ & $1: 1.15$ \\
\hline 3 & 100 & 400 & 25 & $16: 1$ & $1: 2.8$ \\
\hline 4 & 100 & 400 & 30 & $13: 1$ & $1: 3.5$ \\
\hline 5 & 100 & 400 & 40 & $10: 1$ & $1: 4.6$ \\
\hline
\end{tabular}

*The amount of water was dependent by the content of PO fibres in the mortar

\subsection{Determination of density and mechanical resistance}

Density of the prismatic specimen was determined after weighing them. Since the dimensions of samples were $4 \times 4 \times 16 \mathrm{~cm}^{3}$, the

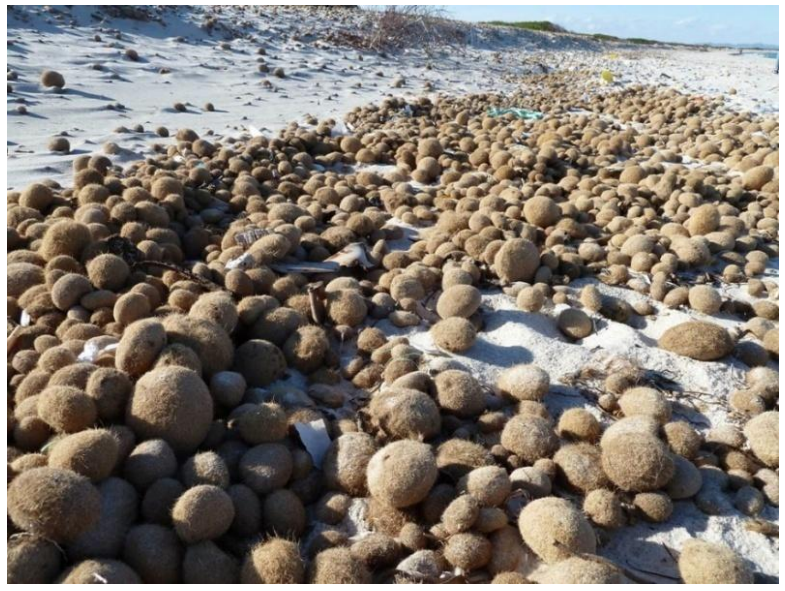

Figure 1. Posidonia Oceanica balls in the coastal area of Durres

Slika 1. Posidonia Oceanica loptice u primorskom delu Drača

\section{2. $P$ composites}

The first process was untwisting the PO balls. The untwisting was an easy process and was done by hand. The following process was the manufacture of mortar with various amounts of fibres. Table 1 presents the ratio of stone and PO fibres. The amount of cement for each case was $100 \mathrm{~g}$. The water cement ratio was variable and depended on the amount of PO fibres added in the mortar. The addition of fibres worsened the workability of mortar since they have the ability to absorb water, therefore, more water needed in each case. After the blending the mixture was poured into the mold to make specimen. Prismatic specimens with dimensions $40 \times 40 \times 160 \mathrm{~mm}^{3}$ were prepared from mortar-fibre mixture. After forming the specimens were kept at ambient temperature for 28 days. 
operation is presented in Figure 1. Eight different samples were tested and the flexural strength was calculated using the following formula (Eq. 1):

$$
\sigma_{f}=\frac{3 f_{\max } L}{2 b h^{2}}
$$

Where $f_{\max }$ stands for the maximal flexural force in $\mathrm{N}, L$ is the distance between supports $(\mathrm{mm})$ and $b$ and $h$ are respectively the width and the height of the prismatic specimen.

Along with the flexural resistance, the compressive resistance was determined. Results are presented in the Figure 2.

\section{RESULTS AND DISCUSSION}

The experimental investigation of the mechanical properties of concrete blocks with various ratios of aggregate and fibres was carried out. Results are presented in the Figure 2. The graph in figure 2 illustrates the mechanical resistance (flexural and compressive) as well as density. From the graph it can be seen that there is a decrease in mechanical properties and density. Flexural resistance varied form 9.41 $\mathrm{MPa}$ for the sample without fibres to $4.14 \mathrm{MPa}$ for the sample with the maximum amount of fibres. The compressive strength was also decreased from 37.02 to $6.3 \mathrm{MPa}$. Along with the considerable decrease of mechanical resistance, a decrease of density was also noticed. Density varied from 2. 22 to $1.36 \mathrm{~g} / \mathrm{cm}^{3}$.

A considerable amount of aggregate is replaced with fibres which have lower density. Moreover, it seems that the addition of PO fibres increases the number of voids and pores, and eventually, the density decreases.

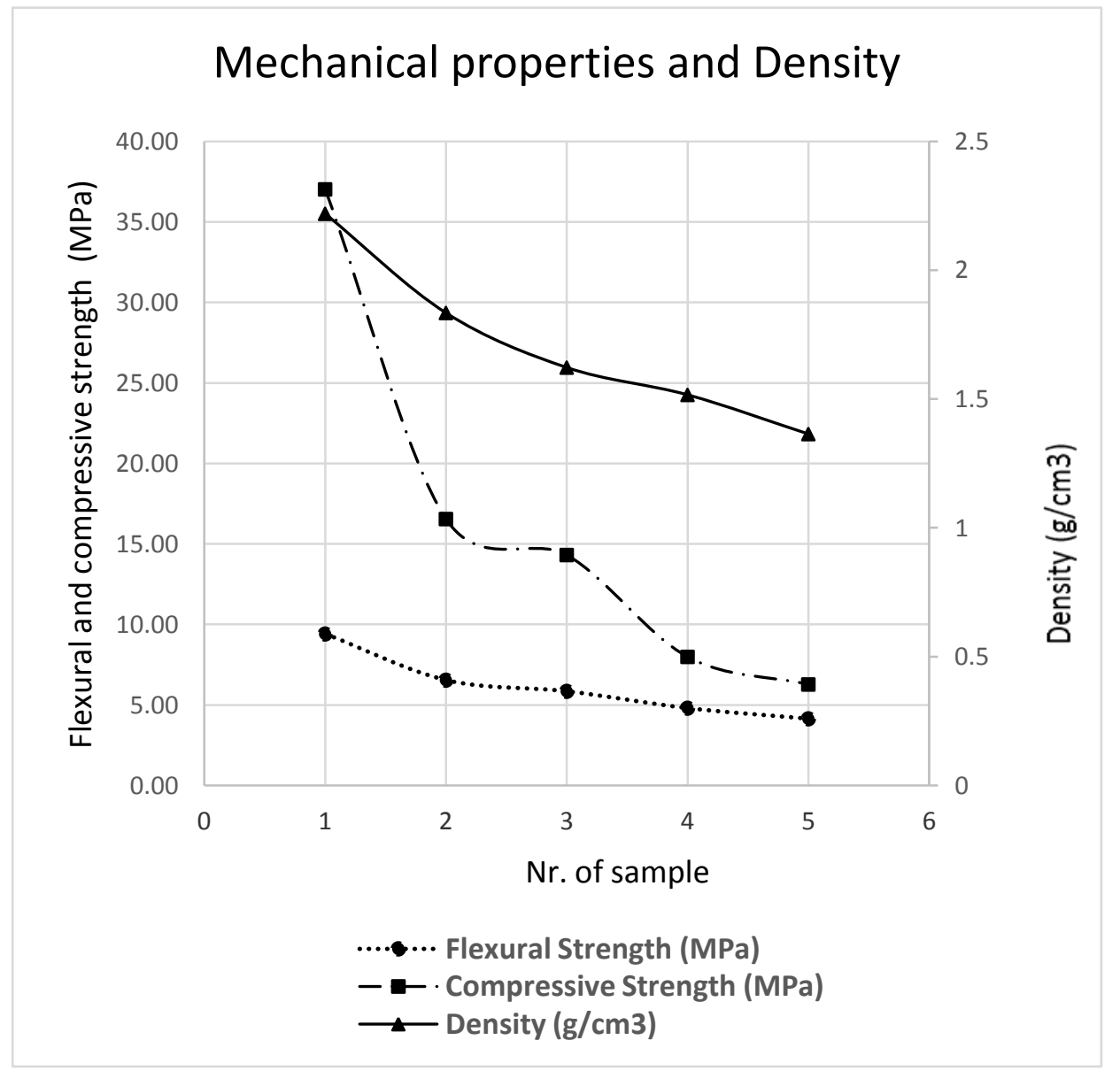

Figure 2. Mechanical properties and density of concrete with PO fibres

\section{Slika 2. Mehanička svojstva i gustina betona sa PO vlaknima}

The decline of density has a positive effect in material properties because now it can be considered as lightweight concrete. Additionally, insulation properties of the material are expected to improve since air and cellulosic fibres in the interior part of concrete specimen have lower thermal conductivity. 
On the other side, mechanical properties were worsened because of the presence of voids. Many previous investigations have claimed that the porosity affects the flexural strength. It has been shown that the flexural strength decreases exponencially with the volume fraction porosity [12]. Along with the decrease of mechanical resistance, material has gained the ability of warning when failed. Failure of ceramic materials has always been a problem not only because as brittle they absorb low amount of energy but also because when fail they tend to collapse in an exeptional way, without warning. The failure without warning may have catastrofic consequences.

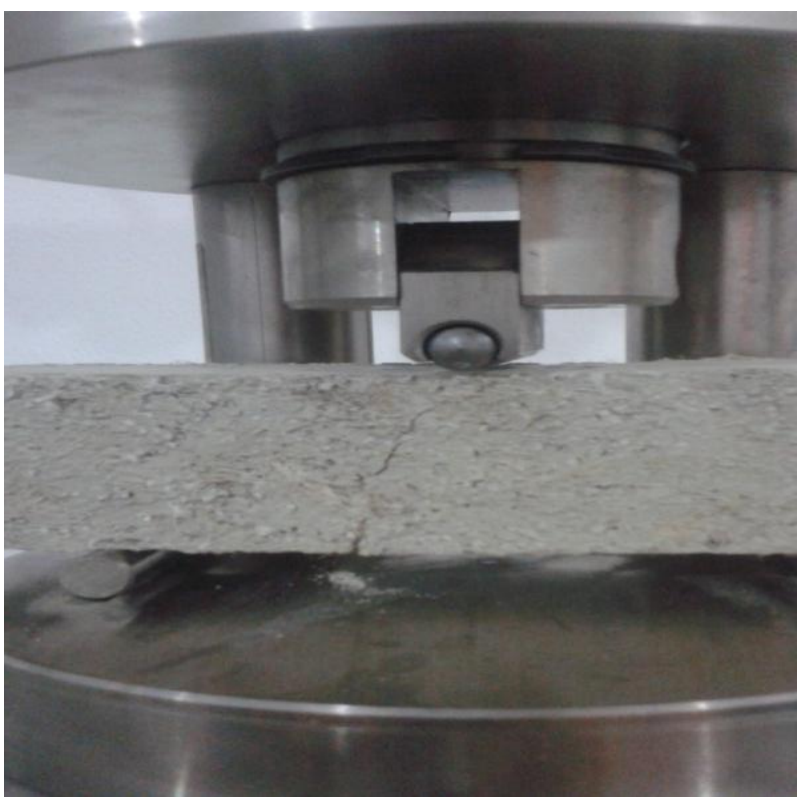

Figure 3. Operation of testing the flexural strength of composite sample

Slika 3. Test ispitivanja jačine savijanja kompozitnog uzorka

During the three point test it was observed that speciments with fibres differently with the first one without fibres had tendency to maintain their structure even though a crack was formed and material had failed.

\section{CONCLUSION}

Composites with concrete as matrix and $\mathrm{PO}$ fibres as reinforcing agent were examinated. The addition of cellulosic fibers worsened the mechanical properties of the final product but had a positive efect in density. The composite can be considered as a lightweight concrete and used in non-structural applictions. It is expected that thermal insulation properties are improved. Observation of the flexural test showed that concrete blocks with fibres can fail with warning since the (they) maintain their structure after crack formation. This work has investigated only some of the properties. Further experimental investigations are reccommended towards thermal and acoustic insulation, pretreatment of cellulose fibre and other physical properties such water absorption and fire resistance.

\section{REFERENCES}

[1] G.Ofori, C.Briffett, G.Gang, M.Ranasinghe (2000) Impact of ISO 14000 on construction enterprises in Singapore, Constr. Manag. Econ., 18, 935-947.

[2] J. Marku (2012) Materiale ndertimore ekologjike. book, EDLORA. Tirane

[3] Z.Li, X.Wang, L.Wang (2006) Properties of hemp fibre reinforced concrete composites, Composites Part A., 37, 497-505.

[4] H.Savastano, P.Warden, R.Coutts (2003) Mechanically pulped sisal as reinforcement in cementitious matrices, Cem Concr Compos, (2003); 25, 311-9.

[5] R.D.Toledo Filho, K.Joseph, K.Ghavami, et al. (1999) The use of sisal fiber as reinforcement in cement based composites, Rev Bras Eng Agri'c Ambient, 3,245-256.

[6] M.S.Islam, S.J.Ahmed (2018) Influence of jute fiber on concrete properties, Construction and Building Materials., 189, 768-776.

[7] L.Allegue, M.Zidi, S.Sghaier (2014) Mechanical properties of Posidonia oceanic fibers reinforced cement, Journal of Composite Materials., 12(1), 1-9.

[8] B.Ferrero, T.Boronat, F.Moriana, et al. (2013) Green composites based on wheat Gluten Matrix and Posidonia Oceanica waste fibers as reinforcements, Polym. Compos., 34,1663-1669.

[9] D.Puglia, R.Petruci, F.Luzi, et al. (2014) Revalorisation of PosidoniaOceanica as Reinforcement in Polyethylene/Maleic Anhydride Grafted Polyethylene Composites, Journal of Renewable Materials, 2, 66-76.

[10] D.G.Garcia, L.Q.Carrillo (2017) Montanes N et al. Manufacturing and Characterization of Composite Fibreboards with Posidonia oceanic Wastes with an Environmentally-Friendly Binder from Epoxy Resin, Materials., 23, 11-35.

[11] EN 196-1:2005 Methods of testing cement - Part 1: Determination of strength.

[12] D.Callister William (2007) Materials science and Engineering. book, John Willey and Sons. New York 


\section{IZVOD}

\section{MEHANIČKE OSOBINE LAKOG BETONA SASTAVLJENOG OD POSIDONIA OCEANICA VLAKNA}

Ovaj rad ima za cilj dobijanje lakog betona sa lignoceluloznim vlaknima iz loptica Posidonia Oceanica. PO loptice se mogu naći u velikim količinama duž obale Mediterana. Na osnovu prethodnih naučnih istraživanja ustanovljeno je da ove materije imaju veoma interesantna svojstva poput otpornost na vatru, otpornost na vlagu i toplotne otpornosti i mogu poslužiti kao sirovina za proizvodnju kompozita po veoma niskoj ceni. U tekućem istraživanju pokušava se ispitati otpornost na pritisak i savojna čvrstoća PO vlakna betona. Rezultati dobijeni testovima pokazuju da se PO vlakna mogu koristiti kao zamena za agregat kojim se dobija laki beton.

Ključne reči: prirodna vlakna, morska trava, Posidonia Oceanica, lagan beton.

Naučni rad

Rad primljen: 15.10.2018.

Rad prihvaćen: 08.11.2018.

Rad je dostupan na sajtu: www.idk.org.rs/casopis

(C) 2018 Authors. Published by Engineering Society for Corrosion. This article is an open access article distributed under the terms and conditions of the Creative Commons Attribution 4.0 International license (https://creativecommons.org/licenses/by/4.0/) 